\title{
STUDI PERBANDINGAN PENDAPATAN USAHATANI PADI ORGANIK DAN PADI NON ORGANIK DI DESA AIK DEWA KECAMATAN PRINGGASELA KABUPATEN LOMBOK TIMUR
}

\section{COMPARATIVE STUDY OF FARMING INCOME OF ORGANIC RICE AND NON-ORGANIK RICE AT AIK DEWA VILLAGE ON PRINGGASELA DISTRICT IN EAST LOMBOK REGENCY}

\author{
Mursyidin Hadi ${ }^{*}$, Bambang Dipokusumo ${ }^{2}$, M. Zubair ${ }^{3}$ \\ ${ }^{1}$ Mahasiswa Program Studi Agribisnis, Fakultas Pertanian, Universitas Mataram \\ ${ }^{2,3}$ Dosen Program Studi Agribisnis, Fakultas Pertanian, Universitas Mataram \\ "Email: hadi.mursyidin@gmail.com
}

\begin{abstract}
ABSTRAK
Penelitian ini bertujuan untuk mengkaji tingkat pendapatan usahatani padi organik dan padi non organik, mengkaji tingkat efisiensi penggunaan biaya produksi pada usahatani padi organik dan padi non organik, menganalisis faktor-faktor apa saja yang mempengaruhi pendapatan usahatani padi organik dan padi non organik. Penelitian ini dilaksanakan di Desa Aik Dewa Kecamatan Pringgasela, dengan metode komparatif dan teknik survey yaitu mewawancarai 70 petani responden yang terdiri dari 35 petani padi organik dan 35 petani padi non organik dengan berpedoman pada questioner. Hasil penelitian menunjukkan bahwa, pendapatan usahatani padi organik di Desa Aik Dewa sebesar Rp 14.361.941,23 per hektar dan pendapatan usahatani padi non-organik sebesar Rp 12,464,247.92 per hektar. Penggunaan biaya produksi usahatani padi non-organik lebih kecil daripada penggunaan biaya produksi usahatani padi organik dengan nilai Rp 6.189.873,95 per hektar untuk usahatani padi non-organik dan $\mathrm{Rp}$ 8.038.058,77 per hektar untuk usahatani padi organik. Selain itu, ditunjukkan dengan perbedaan $R / C$ Ratio padi non-organik lebih efisien dari pada $R / C$ Ratio padi organik dengan nilai 3,01 untuk padi non-organik dan 2,79 untuk padi organik. Faktor-faktor yang mempengaruhi pendapatan usahatani padi organik dan padi non-organik adalah luas lahan, biaya produksi, produktivitas dan sistem budidaya, sedangkan faktorfaktor lain seperti, pendidikan dan pengalaman tidak berpengaruh nyata terhadap pendapatan usahatani padi organik dan non-organik di Desa Aik Dewa Kecamatan Pringgasela.
\end{abstract}

Kata Kunci: Usahatani, Padi organik, Padi Non Organik, Pendapatan

\begin{abstract}
This study aims to determine the level income of organic rice and non-organic rice farming, assessing the level efficiency of production costs on organic rice and non-organic rice farming, and analyzing what is the factors that affect the income of organic rice and non-organic rice farming. This research was conducted in Aik Dewa Village, Pringgasela District, with a comparative method and survey technique by interviewing 70 respondent farmers who consist of 35 organic rice farmers and 35 non-organic rice farmers based on the questionnaire. The results showed that the income of organic rice farming in Aik Dewa Village was $R p$ 14.361.941,23 per hectare and non-organic rice farming income was Rp 12.464.247,92 per hectare. The use of non-organic rice production costs is smaller than the use of organic rice production costs with a value of $R p$ 6.189.873,95 per hectare for non-organic rice farming and $\mathrm{Rp} 8.038 .058,77$ per hectare for organic rice farming. In addition, it is indicated by the difference in $R / C$ ratio of non-organic rice which is more efficient than $R / C$ ratio of organic rice with a value of 3.01 for non-organic rice and 2.79 for organic rice. The factors that influence the income of organic rice farming and non-organic rice are land area, production costs, productivity and cultivation systems, while other factors such as education and experience do not significantly affect the income of organic and non-organic rice farming in the Aik Dewa Village, District of Pringgasela.
\end{abstract}

Keywords: Farms, Organic Rice, Non-organic Rice, Income 


\section{PENDAHULUAN}

Pemerintah Indonesia memberikan komitmen tinggi terhadap pembangunan ketahanan pangan sebagai komponen strategis dalam pembangunan nasional yang diatur dalam Undang-undang No.18 Tahun 2012 tentang pangan. Untuk membangun ketahanan pangan maka disusunlah strategi induk pembangunan pertanian (SIPP) 2015-2045 sebagai bagian dari pelaksanaan amanat konstitusi. Dalam strategi induk pembangunan pertanian (SIPP) 2015-2045 Republik Indonesia telah disusun tujuh pilar dan strategi utama dalam mewujudkan visi pembangunan pertanian yang berkelanjutan. (Kementerian Pertanian, 2014). Salah satu tanaman pangan yang strategis disektor pertanian adalah padi (beras). Peran padi (beras) sebagai makanan pokok di Indonesia sampai saat ini sulit disubstitusikan dengan jenis makanan pokok yang lain. Bahkan ketergantungan terhadap komoditi beras seperti virus yang tak terkendali (Septiadi, 2019).

Semakin tumbuhnya kesadaran akan pentingya menjaga lingkungan, muncul varietas jenis padi organik. Pada tahun 2016 Indonesia mengembangkan padi organik dalam sekala besar yang tersebar di 25 Provinsi dan 169 kabupaten di Indonesia dengan total luas lahan 4.000 hektar. Diantara 25 Provinsi tersebut, Nusa Tenggara Barat merupakan salah satu provinsi terpilih untuk pengembangan desa pertanian organik. Salah satu Kabupaten yang menjadi sasarannya adalah Kabupaten Lombok Timur yang terletak di Desa Aik Dewa Kecamatan Pringgasela. (Kementerian Pertanaian, 2015).

Desa Aik Dewa Kecamatan Pringgasela yang mengembangkan usahatani padi organik berada di bawah binaan Unit Pelayanan Pertanian Kecamatan Pringggasela mempunyai keadaan iklim yang cocok untuk usahatani padi dan kebanyakan penduduknya adalah bekerja di sektor partanian. Hal tersebut membuat petani berharap dengan beralih dari sistem pertanian konvensional menuju pertanian organik mampu meningkatkan pendapatan petani, karena harga jual produk organik lebih tinggi dibandingkan produk non organik. Selain itu, cara bertanam padi organik pada dasarnya tidak berbeda dengan bertanam padi secara konvensional (padi non organik).

Hal inilah yang menyebabkan peneliti ingin mengetahui apakah pendapatan usahatani padi organik di Desa Aik Dewa Kecamatan Pringgasela lebih besar dari pada pendapatan usahatani padi non organik, sehingga yang menjadi pertanyaan sekarang apakah pendapatan usahatani padi organik di Desa Aik Dewa Kecamatan Pringgasela berbeda dengan pendapatan usahatani padi non organik. Namun masih sedikit yang mengangkat masalah usahatani padi organik khususnya di Nusa Tenggara Barat. Bertitik tolak dari latar belakang tersebut peneliti ingin mengetahui perbandingan pendapatan usahatani padi organik dan padi non organik di Desa Aik Dewa Kecamatan Pringgasela Kabupaten Lombok Timur.

Tujuan dari penelitian ini adalah: 1) Untuk mengkaji tingkat pendapatan usahatani padi organik dan padi non organik di Desa Aik Dewa Kecamatan Pringgasela; 2) Untuk mengkaji tingkat efisiensi penggunaan biaya produksi pada usahatani padi organik dan padi non organik di Desa Aik Dewa Kecamatan Pringgasela; 3) Untuk menganalisis faktor-faktor apa saja yang mempengaruhi pendapatan usahatani padi organik dan padi non organik di Desa Aik Dewa Kecamatan Pringgasela.

Dalam penelitian ini, ada tiga hipotesis, yaitu: 1) Terdapat perbedaan yang nyata antara pendapatan usahatani padi organik dan padi non organik di Desa Aik Dewa Kecamatan Pringgasela; 2) Tedapat perbedaan yang nyata antara efisiensi biaya produksi usahatani padi organik dan padi non organik di Desa Aik Dewa Kecamatan Pringgasela; 3) Faktor-faktor yang berpengaruh terhadap pendapatan usahatani padi organik maupun non organik adalah biaya produksi, luas lahan, produktivitas, tingkat pendidikan, pengalaman petani, dan sistem budidaya yang digunakan petani.

\section{METODE PENELITIAN}

Penelitian ini menggunakan metode deskriptif dan komparatif. Metode komparatif yaitu metode yang digunakan untuk membandingkan dua atau lebih fenomena yang berbeda (Nazir, 1999 dalam Nafsiyah, 2004). Unit analisis dalam penilitian ini adalah usahatani padi organik dan usahatani padi non organik di Desa Aik Dewa Kecamatan Pringgasela. Penentuan daerah sampel dilakukan secara sengaja dengan pertimbangan bahwa jumlah dusun di Aik Dewa hanya sedikit dan lokasi dari dusun satu dengan yang lain tidak terlalu jauh. Jumlah populasi petani padi organik 38 orang dan populasi petani padi non organik 687 orang. Sehingga dipilihlah 70 orang responden yang terdiri dari 35 responden petani organik dan 35 responden petanin non organik diman yang terlibat ditentukan dengan Accidental Sampling. Jenis data yang digunakan adalah data kuantitatif dan data kualitatif.

Untuk mengkaji tingkat pendapatan petani padi organik dan non organik adalah dengan menggunakan analisis biaya dan pendapatan. (Soekartawi, 1995 dalam Atmasari 2016).

$\mathrm{I}=\mathrm{TR}-\mathrm{TC}$

Keterangan:

$\mathrm{I}=$ Pendapatan Usahatani (Rp)

$\mathrm{TR}=$ Total Penerimaan $(\mathrm{Rp})$

$\mathrm{TC}=$ Total Biaya $(\mathrm{Rp})$.

Untuk mengkaji tingkat efisiensi penggunaan biaya produksi digunakan analisis R/C ratio yang menunjukkan besarnya pendapatan kotor yang diterima untuk setiap yang dikeluarkan untuk produksi, dengan formulasi sebagai berikut (Hermanto, 1996 dalam Sariwani, 2016): 
$R / C=\frac{T R}{T C}$

Kriteria:

$\mathrm{R} / \mathrm{C}>1$ menunjukkan bahwa usaha layak diusahakan

$\mathrm{R} / \mathrm{C}<1$ menunjukkan bahwa usaha tidak layak diusahakan

Untuk mengetahhui faktor-faktor yang berpengaruh terhadap pendapatan per hektar usahatani padi organik dan padi non organik digunakan uji Regresi Linear Berganda (Wibowo, 1990 dalam Nafsiyah, 2004)).

\section{Keterangan:}

$$
Y=a+b_{1} X_{1}+b_{2} X_{2}+b_{3} X_{3}+b_{4} X_{4}+b_{5} X_{5}+b_{6} X_{6}
$$

$$
\begin{array}{ll}
\mathrm{Y} & =\text { Pendapatan (Rp/ha) } \\
\mathrm{a} & =\text { Konstanta } \\
\mathrm{b} 1-\mathrm{b} 7 & =\text { Koefisien regresi } \\
\mathrm{X}_{1} & =\text { Luas lahan (ha) } \\
\mathrm{X}_{2} & =\text { Biaya produksi }(\mathrm{Rp} / \mathrm{ha}) \\
\mathrm{X}_{3} & =\text { Produktivitas }(\mathrm{kg} / \mathrm{ha}) \\
\mathrm{X}_{4} & =\text { Pendidikan (tahun) } \\
\mathrm{X}_{5} & =\text { Pengalaman (tahun) } \\
\mathrm{X}_{6} & =\text { Sistem budidaya }
\end{array}
$$

\begin{tabular}{|c|c|c|c|c|c|c|c|}
\hline \multirow[b]{2}{*}{ Varietas Padi } & \multicolumn{6}{|c|}{ Kisaran Umur Responden } & \multirow{2}{*}{$\begin{array}{l}\text { Total Jumlah } \\
\text { Responden } \\
\text { (orang) }\end{array}$} \\
\hline & $\begin{array}{l}<15 \text { th } \\
\text { (org) }\end{array}$ & $\%$ & $\begin{array}{l}\text { 15-60th } \\
\text { (org) }\end{array}$ & $\%$ & $\begin{array}{l}>60 \text { th } \\
\text { (org) }\end{array}$ & $\%$ & \\
\hline Organik & - & 0 & 34 & 97,14 & 1 & 2,86 & 35 \\
\hline Non Organik & - & 0 & 28 & 80,00 & 7 & 20,00 & 35 \\
\hline
\end{tabular}

Variabel dummy:

$$
\begin{array}{ll}
\left(d_{1}\right) & =\text { organik } \\
\left(d_{0}\right) & =\text { non organik }
\end{array}
$$

\section{HASIL DAN PEMBAHASAN}

\section{Karakteristik Responden}

Karakteristik petani responden merupakan latar belakang yang mempengaruhi langsung terhadap kegiatan usahatani yang dilakukan.

\section{Umur Responden}

Tabel 1. Kisaran umur petani responden di Desa Aik Dewa Kecamatan Pringgasela tahun 2017

Sumber: Data primer Diolah

Dari rata-rata umur responden pada table 1 dapat dikatakan umur responden petani organik maupun nonorganik berada pada golongan umur produktif. Keadaan ini sesuai dengan pendapat Simanjuntak (1985) dalam Atmasari (2016) yang menyatakan bahwa golongan umur produktif berkisar antara 15-64 tahun.

\section{Tingkat Pendidikan}

Tabel 2. Tingkat pendidikan petani responden di Desa Aik Dewa Kecamatan Pringgasela tahun 2017 


\begin{tabular}{lrrrrrr}
\hline & \multicolumn{5}{c}{ Petani Padi } & \multirow{2}{*}{$\begin{array}{c}\text { Jumlah } \\
\text { Tingkat Pendidikan }\end{array}$} \\
\cline { 2 - 6 } & \multicolumn{2}{c}{ Organik } & \multicolumn{2}{c}{ Non-Organik } & (orang) \\
\cline { 2 - 6 } & Jumlah (org) & $\%$ & & Jumlah (org) & $\%$ \\
\hline Tidak Sekolah & 5 & 14,29 & 4 & 11,43 & 9 \\
Tidak Tamat SD & 11 & 31,43 & 5 & 14,29 & 16 \\
Tamat SD & 6 & 17,14 & 15 & 42,86 & 21 \\
Tamat SLTP & 7 & 20,00 & 6 & 17,14 & 13 \\
Tamat SLTA & 5 & 14,29 & 3 & 8,57 & 8 \\
S1 & 1 & 2,86 & 2 & 5,71 & 3 \\
\hline Jumlah & 35 & 100,00 & 35 & 100,00 & 70 \\
\hline
\end{tabular}

Sumber: Data primer Diolah

Dilihat dari table 2 menunjukkan tingkat pendidikan yang paling banyak ditempuh secara keseluruhan tingkat pendidikan petani responden paling banyak tamat SD sebanyak 21 petani responden.

Jumlah Tanggungan Keluarga

Tabel 3. Sebaran Responden berdasarkan Jumlah tanggungan keluarga di Desa Aik Dewa Kecamatan Pringgasela tahun 2017

\begin{tabular}{|c|c|c|c|c|c|}
\hline \multirow{3}{*}{$\begin{array}{l}\text { Kisaran } \\
\text { Tanggungan }\end{array}$} & \multicolumn{4}{|c|}{ Petani Padi } & \multirow{3}{*}{$\begin{array}{l}\text { Jumlah } \\
\text { (orang) }\end{array}$} \\
\hline & \multicolumn{2}{|c|}{ Organik } & \multicolumn{2}{|c|}{ Non-Organik } & \\
\hline & Jumlah (org) & $\%$ & Jumlah (org) & $\%$ & \\
\hline $1-2$ & 17 & 48,57 & 8 & 22,86 & 25 \\
\hline $3-4$ & 17 & 48,57 & 23 & 65,71 & 40 \\
\hline$\geq 5$ & 1 & 2,86 & 4 & 11,43 & 5 \\
\hline Jumlah & 35 & 100,00 & 35 & 100,00 & 70 \\
\hline
\end{tabular}

Sumber: Data primer Diolah

Berdasarkan table 3 diatas menunjukkan bahwa petani padi organik tergolong kedalam keluarga menengah dan keluarga kecil karena sama-sama berjumlah 17 orang petani responden $(48,57 \%)$. Untuk petani padi nonorganik di dominasi oleh keluarga menengah yang berjumlah 23 orang petani responden $(65,71 \%)$.

\section{Pekerjaan Sampingan}

Tabel 4. Sebaran Responden berdasarkan pekerjaan sampingan yang dimiliki petani di Desa Aik Dewa Kecamatan Pringgasela tahun 2017

\begin{tabular}{|c|c|c|c|c|c|}
\hline \multirow{3}{*}{$\begin{array}{l}\text { Pekerjaan } \\
\text { Sampingan }\end{array}$} & \multicolumn{4}{|c|}{ Petani Padi } & \multirow{3}{*}{$\begin{array}{l}\text { Jumlah } \\
\text { (orang) }\end{array}$} \\
\hline & \multicolumn{2}{|c|}{ Organik } & \multicolumn{2}{|c|}{ Non-Organik } & \\
\hline & Jumlah (org) & $\%$ & Jumlah (org) & $\%$ & \\
\hline Punya & 21 & 60,00 & 16 & 45,71 & 37 \\
\hline Tidak punya & 14 & 40,00 & 19 & 54,29 & 33 \\
\hline Jumlah & 35 & 100,00 & 35 & 100,00 & 70 \\
\hline
\end{tabular}

Sumber: Data primer Diolah

Berdasarkan table 4 diatas untuk petani responden padi organik lebih banyak yang memilik pekerjaan sampingan yaitu sebanyak 21 orang petani responden $(60 \%)$ sedangkan untuk responden petani padi non-organik sebesar 16 orang petani responden $(45,71 \%)$. Sebagian besar pekerjaan sampingan petani responden tidak jauh dari bidang pertanian seperti peternak dah buruh tani, dan sisanya seperti wiraswasta dan kuli bangunan.

Analisis Biaya dan Pendapatan Usahatani Padi Organik dan Padi Non-Organik di Desa Aik Dewa Kecamatan Pringgasela Kabupaten Lombok Timur Tahun 2016

Tabel 5. Analisis Biaya dan Pendapatan Usahatani Padi Organik dan Padi Non-Oragnik di Desa Aik Dewa Kecamatan Pringgasela Kabupaten Lombok Timur Tahun 2016 


\begin{tabular}{|c|c|c|c|c|c|c|}
\hline \multirow{3}{*}{$\begin{array}{c}\text { Jenis Sumberday a Pertanian, } \\
\text { Produksi dan Pendapatan }\end{array}$} & \multicolumn{6}{|c|}{ Us ahatani Padi per Hektar } \\
\hline & \multicolumn{3}{|c|}{ Padi Organik } & \multicolumn{3}{|c|}{ Padi Non-Organik } \\
\hline & Jumlah Fisik & Nilai (Rp.) & $\%$ & Jumlah Fisik & Nilai (Rp.) & $\%$ \\
\hline Luas Garapan (ha) & 1.00 & - & - & 1.00 & - & - \\
\hline Produksi/Penerimaan $(\mathrm{ku})$ & 40.00 & $22,400,000.00$ & - & 53.30 & $18,654,121.86$ & - \\
\hline \multicolumn{7}{|l|}{ Sarana Produksi } \\
\hline a. Benih/Bibit (kg) & 20.12 & $201,156.07$ & 4.75 & 20.61 & $206,093.19$ & 13.13 \\
\hline \multicolumn{7}{|l|}{ b. Pupuk: } \\
\hline Pupuk padat $(\mathrm{kg})$ & $6,500.00$ & $3,250,000.00$ & 76.81 & - & - & - \\
\hline Pupuk cair (btl) & 7.00 & $700,000.00$ & 16.54 & - & - & - \\
\hline Urea $(\mathrm{kg})$ & - & -1 & - & 250.54 & $626,344.09$ & 39.90 \\
\hline SP-36 (kg) & - & - & - & 150.00 & $450,000.00$ & 28.67 \\
\hline \multicolumn{7}{|l|}{ c. Pestisida : } \\
\hline Bio Pestisida (ltr) & 2.00 & $80,000.00$ & 1.89 & - & - & - \\
\hline Regent (btl) & - & - & - & 0.72 & $28,225.81$ & 1.80 \\
\hline Prevathon (btl) & - & - & - & 1.16 & $93,637.99$ & 5.97 \\
\hline Desis (btl) & - & - & - & 1.52 & $58,691.76$ & 3.74 \\
\hline Comfidor (bks) & - & - & - & 0.81 & $25,089.61$ & 1.60 \\
\hline virtaco (btl) & - & - & - & 0.63 & $68,100.36$ & 4.34 \\
\hline Metindo (bks) & - & - & - & 0.27 & $13,440.86$ & 0.86 \\
\hline Total Biaya Saprodi & & $4,231,156.07$ & 54.99 & & $1,569,623.66$ & 27.07 \\
\hline \multicolumn{7}{|l|}{ Tenaga Kerja : } \\
\hline TK Dalam Keluarga (HKO) & 21.97 & $907,658.96$ & 26.21 & 37.42 & $1,614,566.86$ & 38.19 \\
\hline TK Luar Keluarga (HKO) & 32.39 & $2,555,130.06$ & 73.79 & 48.87 & $2,613,306.38$ & 61.81 \\
\hline Total Biaya TK & & $3,462,789.02$ & 45.01 & & $4,227,873.24$ & 72.93 \\
\hline Total Biaya Variabel (Rp) & & $7,693,945.09$ & 95.72 & & $5,797,496.90$ & 93.66 \\
\hline \multicolumn{7}{|l|}{ Biay a Tetap dan Lain-lain: } \\
\hline a. Pajak Ipeda (Rp) & & $46,666.67$ & 13.56 & & $39,053.17$ & 9.95 \\
\hline b. Penyusutan Alat (Rp) & & $65,077.07$ & 18.91 & & $111,657.22$ & 28.46 \\
\hline c. Pembelian Alat $(\mathrm{Rp})$ & & - & $\ldots$ & & - & - \\
\hline d. Iuran Irigasi $(\mathrm{Rp})$ & & $200,000.00$ & 58.12 & & $200,000.00$ & 50.97 \\
\hline e. Transportasi saprodi ( $\mathrm{Rp}$ ) & & $32,369.94$ & 9.41 & & $41,666.67$ & 10.62 \\
\hline Total Biaya Tetap (Rp) & & $344,113.68$ & 4.28 & & $392,377.05$ & 6.34 \\
\hline Total Biaya Produksi (Rp) & & $\mathbf{8 , 0 3 8 , 0 5 8 . 7 7}$ & & & $6,189,873.95$ & \\
\hline Pendapatan (Rp) & & $14,361,941.23$ & & & $12,464,247.92$ & \\
\hline R/C Ratio & & 2.79 & & & 3.01 & \\
\hline
\end{tabular}

Sumber: Data primer diolah

Berdasarkan Tabel 5 menunjukkan bahwa rata-rata produksi fisik usahatani padi organik sebanyak 40 kuintal memperoleh nilai produksi Rp.22.400.000,00 per hektar. Sementara itu, usahatani padi non-organik, ratarata produksi fisik mencapai 53,30 kuintal dengan nilai produksi Rp 18.654.121,86 per hektar.

Biaya produksi yang dimaksud ialah biaya yang dibutuhkan untuk usahatani padi organik dan non organik baik dikeluarkan secara langsung maupun tidak langsung yang meliputi biaya variabel, biaya tetap, dan biaya lainlain.

1). Biaya Variabel

Biaya variabel meliputi biaya sarana produksi dan biaya tenaga kerja dengan rata-rata biaya variabel $\mathrm{Rp}$ 7.694.945,09/ha untuk usahatani padi organik dan Rp 5.797.496,90/ha untuk usahatani padi non organik dengan selisih biaya sebesar Rp 1.897.448,49/ha. Penggunaan biaya variabel pada usahatani padi organik sekitar 95,72 $\%$ dari total biaya dan $93,66 \%$ dari total biaya untuk usahatani padi non-organik.

(a). Biaya Sarana Produksi

Sarana produksi benih yang digunakan dalam 1 hektar rata-rata 20,12 kg padi organik dan 20,61 kg padi non organik sehingga nilai sarana produksi untuk padi organik adalah Rp 4.231.156,07 per hektar sedangkan untuk padi non organik adalah Rp 1.569.623,66 per hektar. Tabel 5 menunjukkan bahwa biaya sarana produksi yang paling tinggi pada usahatani padi organik maupun padi non-organik adalah biaya penggunaan pupuk. Namun jika dibandingkan biaya penggunaan pupuk padi organik dengan padi non-organik maka biaya pupuk padi organik 
lebih besar Rp 2.873.655,91 per hektar. Biaya penggunaan pupuk yang tinggi pada usahatani padi organik dikarenakan penggunaan pupuk organik dalam jumlah yang sangat besar yatiu $6.500 \mathrm{~kg}$.

(b). Biaya Tenaga Kerja

Tabel 5 menunjukkan bahwa penggunaan biaya variabel terbesar pada usahatani padi organik dan non organik adalah biaya penggunaan tenaga kerja luar keluarga, berdasarkan perhitungan HKO yaitu 32,39 HKO pada tingkat upah Rp 2.555.130,06 per hektar usahatani padi organik dan 48,87 HKO dengan nilai tenaga kerja Rp 2.613.306,38 per hektar usahatani padi non organik.

2) Biaya Tetap

Tabel 5 menunjukkan bahwa biaya tetap terbesar dikeluarkan adalah biaya iuran irigasi sebesar Rp 200.000 untuk usahatani padi organik maupun non organik. Adapun biaya tetap yang paling rendah adalah biaya pajak tanah yaitu Rp 46.666,67 per ha usahatani padi organik dan Rp 39.053,17 usahatani padi non organik. Hal ini disebabkan karena rata-rata petani responden padi organik dan padi non organik memiliki luas lahan yang sempit yakni kurang dari sama dengan 0,50 ha.

Berdasarkan rincian biaya variabel, biaya tetap dan biaya lain-lain tersebut maka diperoleh rata-rata biaya produksi usahatani padi organik sebesar Rp 8.038.058/hektar dan padi non organik sebesar Rp 6.189.873,95/hektar. Jika dilihat pada data tersebut, pendapatan petani responden usahatani padi organik dan padi non organik di Desa Aik Dewa memperoleh pendapatan bersih positif yakni Rp 14.361.941,23/hektar usahatani padi organik dan Rp 12.464.247.92/hektar usahatani padi non organik.

Untuk membuktikan apakah usahatanai padi organik dan padi non organik efisien atau tidak, maka dilakukan perhitungan $\mathrm{R} / \mathrm{C}$ ratio. Revenue Cost Ratio (R/C) merupakan perbandingan antara penerimaan kotor dengan biaya total yang dikeluarkan. Kriteria kelayakan yang digunakan dalam penelitian ini ada dua yakni, jika $\mathrm{R} / \mathrm{C}>1$ menunjukkan bahwa usaha layak diusahakan dan jika $\mathrm{R} / \mathrm{C}<1$ usaha tidak layak dikerjakan.

Dari hasil perbandingan antara total nilai produksi atau penerimaan Rp 22.400.000,00/hektar dengan total biaya produksi padi organik sebesar Rp 8.038.214,40/hektar maka diperoleh nilai R/C ratio usahatani padi organik sebesar 2,79. Pada perhitungan $\mathrm{R} / \mathrm{C}$ ratio usahatani padi non organik yaitu dengan membandingkan total penerimaan Rp 18.654.121,86/hektar dengan total biaya produksi Rp 6.189.873.95/hektar sehingga diperoleh nilai $\mathrm{R} / \mathrm{C}$ ratio sebesar 3,01

Hal ini dapat disimpulkan bahwa usahatani padi organik dan padi non organik sama-sama layak diusahakan karena nilai R/C ratio lebih dari satu. Nilai R/C ratio sebesar 2,79 dapat diartikan bahwa setiap biaya yang dikeluarkan sebesar Rp.100 maka akan memperoleh penerimaan usahatani padi organik sebesar Rp 279, untuk usahatani padi non organik dengan biaya Rp.100 memperoleh penerimaan sebesar Rp 301.

Perbandingan Biaya dan Pendapatan Usahatani Padi Organik dengan Padi Non Organik di Desa Aik Dewa Kecamatan Pringgasela Tahun 2016

Dengan diketahuinya jumlah biaya produksi dan pendapatan maka dapat dilakukan analisis perbandingan biaya, pendapatan serta efisiensi pada usahatani padi organik dengan padi non organik.

Tabel 6 Analisis Perbandingan Biaya dan Pendapatan Usahatani Padi Organik dengan Padi Non Organik di Desa Aik Dewa Kecamatan Pringgasela Tahun 2016

\begin{tabular}{lllll}
\hline \multirow{2}{*}{ No. } & \multirow{2}{*}{ Uraian } & \multicolumn{2}{l}{ Komoditas Usaha } & Selisih (Rp/ha) \\
\cline { 3 - 5 } & & Padi Organik (Rp/ha) & Padi Non Organik (Rp/ha) & \\
\hline 1 & Biaya produksi & $8.038 .058,77$ & $6.189 .873,95$ & $1.866 .679,50$ \\
2 & Nilai produksi & $22.400 .000,00$ & $18.654 .121,86$ & $3.745 .878,14$ \\
3 & Pendapatan & $14.361 .941,23$ & $12,464,247.92$ & $1.897 .693,31$ \\
4 & R/C Ratio & 2,79 & 3,01 & 0,22 \\
\hline
\end{tabular}

Sumber: Data Primer Diolah

Berdasarkan Tabel 6 menunjukkan bahwa rata-rata nilai produksi padi organik yakni Rp 22.400.000,00/ha lebih tinggi daripada rata-rata nilai produksi padi non organik Rp 18.654.121,86/ha dengan selisih Rp 1.866.679,50/ha. Rata-rata nilai produksi padi non organik lebih rendah daripada padi organik disebabkan karena harga per ku padi organik lebih tinggi daipada padi non organik, rata-rata harga per kuintal gabah padi non organik hanya sebesar Rp 350.000 sedangkan rata-rata harga per kuintal gabah padi organik mampu mencapai Rp560.000. Padahal jika dilihat dari segi produksi, rata-rata jumlah produksi padi non organik lebih tinggi daripada padi organik yakni 53,30 kw/ha sedangkan produksi gabah padi organik hanya sebesar 40,00 kw/ha.

Melihat dari segi pendapatan, usahatani padi organik lebih besar daripada padi non organik. Rata-rata pendapatan yang diterima petani responden pada usahatani padi organik sebesar Rp 14.361.785,60 per hektar sedangkang rata-rata pendapatan yang diterima petani responden padi non organik senilai Rp 12,464,247.92 per hektar sehingga menghasilkan selisih pendapatan sebesar Rp 1.897.693,31. Faktor yang mempengaruhi pendapatan petani responden padi non organik lebih rendah dari pada pendapatan petani responden padi organik adalah faktor harga padi non organik yang hanyaRp 350.000/ku sedangkan harga padi non organik Rp 560.000/ku. 
Walaupun nilai produksi padi non organik lebih kecil dibandingkan padi organik akan tetapi untuk nilai koefisien $\mathrm{R} / \mathrm{C}$ ratio, usahatani padi non organik memiliki nilai $\mathrm{R} / \mathrm{C}$ ratio lebih besar yaitu 3,01 jika dibandingkan dengan R/C Ratio padi organik yang hanya sebesar 2,79 dengan selisih 0,22. Kedua usahatani tersebut sama-sama layak untuk diusahakan karena masing-masing nilai $\mathrm{R} / \mathrm{C}$ ratio $>1$, akan tetapi usahatani padi organik relatif lebih besar pendapatannya daripada padi non organik. Pada usahatani padi organik, hanya dengan biaya Rp 100 dapat memperoleh penerimaan sebesar Rp 279 dengan laba sebesar Rp 179, sedangkan usahatani padi non organik dengan biaya Rp 100 memperoleh penerimaan Rp 301 dengan laba sebesar Rp 201.

\section{Hasil Pengujian Hipotesis}

Untuk menguji hipotesis mengenai biaya, pendapatan dan efisiensi usahatani padi organik dengan padi non_organik dilakukan uji t dengan menggunakan aplikasi Microsoft Excel.

\section{Hasil Uji t Biaya Produksi.}

Hasil pengujian hipotesis komparasi dengan Uji t antara biaya produksi padi organik dengan padi nonorganik per hektar dengan membandingkan t-tabel dan t-hitung pada taraf kesalahan ( $\alpha$ ) $5 \%$ didapat hasil, t hitung 4.4262 lebih besar dari t-tabel 2.0066 yang artinya Ho ditolak, maka sesungguhnya ada perbedaan yang nyata antara biaya produksi usahatani padi organik dengan biaya produksi usahatani padi non-organik. Uji t dilakukan setelah melakukan uji $\mathrm{F}$ (homogenitas varians) antara biaya produksi usahatani padi organik dengan usahatani padi non-organik. Hasil uji F menunjukkan, F hitung 3.5940 lebih besar dari F tabel 1.7720 yang berarti varians kedua sampel tidak homogen.

\section{Hasil Uji t Pendapatan}

Hasil uji beda hipotesis yang terlebih dahulu melakukan uji $\mathrm{F}$ untuk mengetahui homogenitas varian antara pendapatan usahatani padi organik dan padi non-organik. Hasil uji $\mathrm{F}$ pada taraf kesalahan $5 \%$ dapat diketahui $\mathrm{F}$ hitung 1.6155 lebih kecil dari $\mathrm{F}$ tabel 1.7721 yang berarti varians kedua sampel homogen.

Hasil perhitungan dari Microsoft Exel 2007 bahwa thitung 3.632 lebih besar dari t tabel 1.995, maka Ho ditolak dengan kesimpulan ada perbedaan nyata antara pendapatan usahatani padi organik dengan padi nonorganik.

\section{Hasil Uji t Efisiensi}

Hasil uji t efisiensi usahatani padi organik dan padi non-organik dengan taraf kesalahan $5 \%$ pada aplikasi Microsoft Excel diperoleh nilai t hitung 1.6167 lebih kecil dari t tabel 1.9955, maka Ho diterima dengan kesimpulan tidak ada perbedaan nyata antara efisiensi usahatani padi organik dengan padi non-organik. Sebelum melakukan uji t, terlebih dulu dilakukan uji $\mathrm{F}$ untuk mengetahui homogenitas varian antara efisiensi usahatani padi organik dan padi non-organik.

Hasil uji $\mathrm{F}$ pada taraf kesalahan 5\% dapat diketahui $\mathrm{F}$ hitung 0.117 lebih kecil dari $\mathrm{F}$ tabel 0.564 yang berarti varians kedua sampel homogen.

Faktor-Faktor Yang Berpengaruh Terhadap Pendapatan Usahatani Padi Organik dan Non Organik di Desa Aik Dewa Kecamatan Pringgasela

Pengujian keseluruhan model regresi mengenai ada atau tidaknya hubungan antara variabel luas lahan (X1), biaya produksi (X2), produktivitas (X3), pendidikan (X4), pengalaman (X5), dan sistem budidaya (X6) yaitu organik $(\mathrm{d}=1)$ dan non_organik $(\mathrm{d}=0)$, secara bersama-sama terhadap variabel $\mathrm{Y}$ yang digunakan uji-F. Besarnya pengaruh masing-masing variabel bebas terhadap pendapatan petani dalam berusahatani padi dapat diketahui, untuk itu dilakukan pengujian terhadap masing-masing koefisien regresi dengan menggunakan uji-t. Hasil uji-F dan uji-t disajikan pada table 7.

Tabel 7. Estimasi Koefisien Regresi Terhadap Pendapatan Petani Padi Organik dan Padi Non-Organik per Ha di Desa Aik Dewa Kecamatan Pringgasela Kabupaten Lombok Timur, Tahun 2016 


\begin{tabular}{llrrrrr}
\hline & Model & \multicolumn{2}{c}{ Unstandardized Coefficients } & $\begin{array}{c}\text { Standardized } \\
\text { Coefficients }\end{array}$ & \multirow{2}{*}{$\mathrm{t}$} & \multicolumn{1}{c}{ Sig. } \\
\cline { 3 - 6 } & (Constant) & -1697867.493 & 279917.715 & & -6.066 & $8.208 \mathrm{E}-08$ \\
\hline 1 & Luas_Lahan & -5632036.253 & 2169881.993 & -0.371 & -2.596 & 0.012 \\
& Biaya_Produksi & 1.219 & 0.172 & 0.564 & 7.067 & $1.526 \mathrm{E}-09$ \\
& Produktivitas & 272132.086 & 28516.680 & 0.788 & 9.543 & $7.526 \mathrm{E}-14$ \\
& Pendidikan & 53693.763 & 43502.482 & 0.017 & 1.234 & 0.222 \\
& Pengalaman & -4674.303 & 5211.276 & -0.013 & -0.897 & 0.373 \\
& Varistac Dadi & 1330719.610 & 159244.798 & 0.161 & 8.356 & $8.506 \mathrm{E}-12$ \\
\hline F-Hitung & Sistem_Budidaya & 1103.940935 & & & & \\
Sig-F & & $8.18645 \mathrm{E}-62$ & & & & \\
Adjusted R Square & 0.99 & & & & \\
\hline
\end{tabular}

Sumber: Data Primer Diolah

Tabel 7 menyatakan bahwa nilai F-hitung sebesar 1103,940935 dengan tingkat signifikansi hitung sebesar 8.18645E-62 yang lebih kecil daripada tingkat signifikansi harapan 0,05. Hal ini berarti seluruh variabel independen secara bersama-sama berpengaruh sangat nyata terhadap pendapatan bersih yang diterima petani padi.

Nilai Adjusted R Square sebesar 0,99 berarti sekitar 99\% pendapatan petani di pengaruhi oleh variabelvariabel dalam model, yaitu luas lahan, biaya produksi, produktivitas, pendidikan, pengalaman, serta barietas padi yang diusahakan dan sisanya $1 \%$ merupakan faktor lain yang tidak dimasukkan dalam model. Adanya konstata sebesar -1697867,493 berarti bahwa sebelum usahatani dilakukan dan tanpa adanya input X1 sampai X6, maka kondisi usahatani sudah mengeluarkan biaya sebesar Rp 1.697.867,49.

Tabel 7 juga menyatakan bahwa yang berpengaruh nyata (secara signifikan) pada taraf kepercayaan $95 \%$ terhadap pendapatan petani padi organik dan padi non_organik adalah luas lahan, biaya, produktivitas, dan jenis padi yang diusahakan. Kemudian untuk variabel yang tidak berpengaruh nyata terhadap pendapatan petani adalah pendidikan dan pengalaman. Jadi, persamaan regresi untuk pendapatan petani padi organik dan padi non-organik adalah;

$Y=-1.697 .867,493-5.632 .036,253 X_{1}+1,219 X_{2}+272.132,086 X_{3}+53.693,763 X_{4}-4.674,303 X_{5}+$ $1.330 .719,610 \mathrm{X}_{6}$

Pengaruh masing-masing faktor dijelaskan sebagai berikut:

\section{a. Faktor Luas Lahan}

Faktor luas lahan (X1) berdasarkan hasil analisis diperoleh koefisien regresi -5.632.036,253 yang artinya bahwa setiap penambahan luas lahan sebesar $1 \mathrm{Ha}$ akan menurunkan pendapatan usahatani per Ha sebesar Rp 5.632.036,25. Hasil uji statistik diperoleh tingkat signifikansi hitung 0,012 lebih kecil dari 0,05 menunjukkan faktor luas lahan berpengaruh nyata terhadap pendapatan usahatani padi per Ha pada taraf kepercayaan $95 \%$ dengan asumsi faktor-faktor lain dianggap tetap.

\section{b. Faktor Biaya Produksi}

Faktor biaya produksi (X2) mempunyai koefisien regresi sebesar 1,219 artinya bahwa setiap penambahan satu rupiah akan meningkatkan pendapatan usahatani per Ha sebesar Rp 1,22. Hasil uji statistik diperoleh tingkat segnifikansi hitung sebesar 1,526E-09 yang lebih kecil dari 0,05 menunjukkan faktor biaya produksi berpengaruh nyata terhadap pendapatan usahatani per Ha pada taraf kepercayaan 95\% dengan asumsi faktor-faktor lain dianggap tetap.

\section{c. Faktor Produktivitas}

Faktor produktivitas (X3) memperoleh koefisien regresi sebesar 272.132,086 berarti setiap kenaikan 1 kuintal produktivitas akan menambahkan pendapatan usahatani per Ha sebesar Rp 272.132,07 Hasil pengujian statistik diperoleh tingkat signifikansi hitung 7,526E-14 kurang dari 0,05 yang berarti faktor produktivitas berpengaruh sangat nyata terhadap pendapatan dengan asumsi faktor-faktor lain dianggap tetap.

\section{d. Faktor Pendidikan}

Faktor pendidikan (X4) mempunyai koefisien regresi sebesar 53.693,763. Ini berarti bahwa setiap kenaikan satu tahun lamanya pendidikan akan meningkatkan pendapatan usahatani per Ha sebesar Rp 53.693,76. Hasil uji statistik diperoleh tingkat signifikansi hitung sebesar 0,222 lebih besar dari 0,05 yang artinya bahwa faktor pendidikan tidak berpengaruh nyata terhadap pendapatan usahatani dengan asumsi faktor-faktor lain dianggap tetap.

\section{e. Faktor Pengalaman}

Pada faktor pengalaman (X5) dari hasil analisis diperoleh koefisien regresi sebesar -4.674,303. Ini berarti bahwa setiap peningkatan satu tahun pengalaman akan menurunkan pendapatan usahatani per Ha sebesar Rp 4.674,30. Hasil uji statistik diperoleh tingkat signifikansi hitung sebesar 0,373 lebih besar dari 0,05 yang artinya 
bahwa faktor pengalaman menunjukkan pengaruh tidak nyata terhadap pendapatan usahatani padi dengan asumsi faktor-faktor lain dianggap tetap.

\section{f. Faktor Sistem Budidaya}

Adapun yang terakhir yaitu faktor sistem budidaya padi yang diusahakan oleh petani (X6). Pada faktor sistem budidaya koefisien regresi yang diperoleh sebesar $1.330 .719,610$ berarti bahwa pemakaian benih padi organik akan meningkatkan pendapatan usahatani padi per Ha sebesar Rp 1.330.719,61. Hasil uji statistik diperoleh tingkat signifikansi hitung 8,506E-12 lebih kecil dari 0,05 yang artinya bahwa sistem budidaya padi organik berpengaruh sangat nyata atau secara signifikan terhadap peningkatan pendapatan usahatani dengan asumsi faktor-faktor lain dianggap tetap.

\section{KESIMPULAN DAN SARAN}

\section{Kesimpulan}

1. Pendapatan usahatani padi organik di Desa Aik Dewa Kecamatan Pringgasela sebesar Rp 14.361.941,23 per hektar dan pendapatan usahatani padi non-organik sebesar Rp 12,464,247.92 per hektar. Pendapatan usahatani padi organik lebih tinggi karena harga jual padi organik yang lebih mahal daripada harga jual padi non-organik.

2. Penggunaan biaya produksi usahatani padi non-organik di Desa Aik Dewa Kecamatan Pringgasela lebih kecil daripada penggunaan biaya produksi usahatani padi organik dengan nilai Rp 6.189.873,95 per hektar untuk usahatani padi non-organik dan $\mathrm{Rp} 8.038 .058,77$ per hektar untuk usahatani padi organik. Selain itu, ditunjukkan dengan perbedaan $R / C$ Ratio padi non-organik lebih efisien dari pada $R / C$ Ratio padi organik dengan nilai 3,01 untuk padi non-organik dan 2,79 untuk padi organik. Artinya, setiap Rp 1 biaya yang dikeluarkan petani memperoleh penerimaan sebesar Rp 3,01 untuk padi non-organik dan Rp 2,79 untuk padi organik.

3. Faktor-faktor yang mempengaruhi pendapatan usahatani padi organik dan padi non-organik adalah luas lahan dengan nilai koefisien $-5.632 .036,253$, biaya produksi dengan nilai koefisien 1,219, produktivitas dengan nilai koefisien 272.132,086 dan sistem budidaya dengan nilai koefisien 1.330.719,610. Sedangkan faktor-faktor lain seperti, pendidikan dan pengalaman tidak berpengaruh nyata terhadap pendapatan usahatani padi organik dan non-organik di Desa Aik Dewa Kecamatan Pringgasela.

Saran

1. Pemerintah hendaknya menyediakan alternatif pendapatan lain bagi petani saat masa transisi dari usahatani padi non-organik ke usahatnai padi organik.

2. Petani padi organik hendaknya tetap mempertahankan sistem usahataninya guna pembangunan lingkungan yang berkelanutan dan hasil produksi padi organik yang berkualitas.

3. Perlu adanya suatu wadah atau kelompok pemasaran padi organik yang terorganisir di Kecamatan Pringgasela agar memiliki daya tawar yang tinggi sehingga lebih dikenal oleh masyarakat.

\section{DAFTAR PUSTAKA}

Atmasari, N. (2016). Studi Waktu Jual Gabah Padi dan Dampaknya Terhadap Pendapatan Petani (Kasus Petani Padi di Desa Pengadangan Kecamatan Pringgasela). [Skripsi, unpublished]. Fakultas Pertanian. Universitas Mataram. Mataram. Indonesia

Kementerian Pertanian. 2014. Strategi Induk Pembangunan Pertanian (SIPP) 2015-2045: Pertanian-Bioindustri Solusi Pembangunan Indonesia Masa Depan. Biro Perencanaan. Jakarta. Indonesia.

Kementerian Pertanian. 2015. Petunjuk Teknis Pengembangan Desa Pertanian Organik Padi 2016. Jakarta. Indonesia.

Nafsiyah, E. Basrid. (2004). Studi Komparatif Efisiensi Biaya dan Pendapatan Usahatani Padi Organik dan Non Organik (Studi Kasus di Kecamatan Mumbulsari Kabupaten Jember). [Skripsi unpublished]. Fakultas Pertanian. Universitas Jember. Jember. Indonesia.

Sariwani. (2016). Studi Komparatif Biaya Dan Pendapatan Usahatani Kacang Tanah Dengan Jagung di Kecamatan Bayan Kabupaten Lombok Utara. [Skripsi, unpublished]. Fakultas Pertanian. Universitas Mataram. Mataram. Indonesia.

Septiadi, D. 2019. Analisis Respon dan Faktor-Faktor yang Mempengaruhi Permintaan Beras Indonesia. Agrimor: Jurnal Agribisnis Lahan Kering. Vol 4 (3) 2019: 42-44. 